\title{
A herança espiritual-carismática de santo Aníbal Maria à luz da espiritualidade de santa Teresa de Jesus
}

\author{
Orientadora: Lúcia Pedrosa de Pádua \\ Doutoranda: Gislene Danielski \\ Área de Concentração: Teologia Sistemático-Pastoral \\ Linha de Pesquisa: Religião e Modernidade \\ Projeto de Pesquisa: Mística, Teologia e Humanização
}

A pesquisa que realizamos fundamenta-se na espiritualidade-carismática de santo Aníbal Maria Di Francia e na doutrina espiritual de santa Teresa de Jesus. Aníbal Maria, através do carisma do Rogate, consagrou sua vida a Deus por meio de uma intensa vida de oração e união a Cristo expressa na caridade em prol dos mais necessitados. Fundou o Instituto das Filhas do Divino Zelo e deu o Rogate como caminho de salvação às suas religiosas e à messe que lhes é confiada. O fundador buscou iluminação para sua vida e para a vida de seu Instituto na espiritualidade carmelita. Em muitos de seus escritos aponta para os santos carmelitas como modelo de vida espiritual e apostólica. Dentre estes, damos destaque à proximidade com santa Teresa de Jesus, doutora da Igreja. Nos escritos da santa de Ávila, Aníbal encontra aspectos que impulsionam a espiritualidade e missão do Rogate. No percurso deste trabalho evidenciamos alguns destes aspectos que incidiram na vida do fundador e que hoje incidem diretamente na espiritualidade-carismática da Filha do Divino Zelo, ressignificando e iluminando o processo de conformação a Cristo dessas religiosas. Destacamos: a oração em santa Teresa, sua profunda contemplação sobre a Sagrada Humanidade de Cristo, o Matrimônio Espiritual, a caridade como reflexo do profundo trato de Amizade com o Divino Esposo, o amor à eucaristia e a Maria. Elementos que colaboram para que a Filha do Divino 
Zelo esteja sempre mais unida ao Divino Esposo e com Ele possa entregar a própria vida pela salvação das almas e para que a Ele se juntem sempre mais "fortes amigos".

Palavras-chave: Oração. Sagrada Humanidade de Cristo. Matrimônio Espiritual. 